\title{
Antiproliferative effects of interferon $\alpha$ on human pancreatic carcinoma cell lines are associated with differential regulation of protein kinase $\mathrm{C}$ isoenzymes
}

\author{
S Rosewicz, M Weder, A Kaiser, E O Riecken
}

\begin{abstract}
Background-The molecular mechanisms mediating the antiproliferative effects of interferon $\alpha$ on human pancreatic carcinoma cells are poorly understood.

Aim-To characterise the effects of interferon $\alpha$ on protein kinase $C$ isoenzyme expression in interferon $\alpha$ sensitive and resistant human pancreatic tumour cell lines.

Methods-The ductal human pancreatic carcinoma cell lines Capan 1 and Capan 2 were investigated. Anchorage dependent and independent growth was determined by cell number and a human tumour clonogenic assay. Interferon $\alpha$ receptor expression was examined by reversetranscriptase polymerase chain reaction and electrophoretic mobility shift assay. Protein kinase C isoenzyme expression was evaluated by western blotting using monospecific polyclonal antibodies.

Results-Interferon $\alpha$ treatment results in a time and dose dependent inhibition of anchorage dependent and independent growth in Capan 1 cells while Capan 2 cells were not affected by interferon $\alpha$. Both cell lines express interferon $\alpha$ receptor mRNA transcripts. Growth inhibition by interferon $\alpha$ in Capan 1 cells was paralleled by a profound decrease of protein kinase $\mathbf{C} \alpha$ and $\zeta$ expression while these isoenzymes were unaffected in the interferon resistant cell line Capan 2.

Conclusion-Inhibition of protein kinase C isoenzyme expression might determine the sensitivity of a given pancreatic carcinoma to respond to the antiproliferative action of interferon $\alpha$.

(Gut 1996; 39: 255-261)
\end{abstract}

Department of

Medizinische Klinik

und Poliklinik,

Klinikum Benjamin

Franklin, Berlin,

Germany

S Rosewicz

$M$ Weder

A Kaiser

E O Riecken

Correspondence to:

Dr S Rosewicz, Department

of Gastroenterology,

Medizinische Klinik und

Poliklinik, Klinikum

Benjamin Franklin,

Hindenburgdamm 30, 12200

Berlin, Germany.

Accepted for publication

27 March 1996
Keywords: pancreatic cancer, interferon, pancreatic growth, protein kinase C.

Pancreatic adenocarcinoma accounts for $25 \%$ of all gastrointestinal cancer related death. ${ }^{1}$ Most patients present with advanced disease at the time of diagnosis and can therefore not be considered for surgical resection. ${ }^{2}$ Conventional chemotherapy has not resulted in a significant survival benefit over the past 30 years, and the average survival time is still measured in months. ${ }^{3}$ Given this therapeutic dilemma, recent research efforts have focused on identifying compounds that might improve the antitumour activity of established chemotherapeutic agents. In this context numerous in vivo and in vitro studies have shown that biological response modifiers such as cytokines or interferons can increase the antiproliferative effects by a variety of mechanisms.

Interferons are a family of naturally occurring glycoproteins that share antiviral, immunomodulatory, and antiproliferative effects. The interaction of interferon $\alpha$ (IFN $\alpha$ ) with 5fluorouracil (5-FU), the mainstay of conventional chemotherapy for pancreatic cancer, has been of particular interest. This is based on the finding that IFN $\alpha$ can increase the cytotoxic effects of 5-FU by a variety of mechanisms such as increased formation of active metabolite, inhibition of thymidine kinase, and decreased thymidine uptake (reviewed in reference 4). In addition to the pharmacological modification of cytotoxic drugs, IFN $\alpha$ displays direct antiproliferative effects on a variety of tumour cells in vivo and in vitro. However, the molecular mechanisms by which IFN $\alpha$ exerts its antiproliferative effects are still poorly understood. After binding to a high affinity plasma membrane receptor, IFN $\alpha$ rapidly but transiently stimulates the transcription of the IFN stimulated gene (ISG) family via at least three IFN inducible transcription factors (reviewed in reference 5). In addition to the transient transcriptional induction of IFN regulated genes, recent experimental evidence suggests, that regulation of protein kinase C (PKC) isoenzyme expression might play a key part in the modulation of growth by IFN $\alpha{ }^{6-9}$ We have recently observed that PKC $\alpha$ plays a central part in maintaining proliferation in human pancreatic carcinoma cells in vitro: stable transfection of a PKC $\alpha$ antisense construct, which results in inhibition of PKC $\alpha$ protein expression, shows significant inhibition of growth in a human pancreatic carcinoma cell line (Rosewicz et al, manuscript in preparation). Based on these findings, the aim of this study was to investigate the effects of IFN $\alpha$ on PKC isoenzyme expression in human pancreatic carcinoma cells and to correlate these effects with IFN $\alpha$ ability to inhibit growth.

\section{Methods}

\section{Materials}

The following cell lines were obtained from the American Type Tissue Culture Collection: human pancreatic carcinoma cell lines Capan 1, Capan 2, and Panc. The human pancreatic 
carcinoma cell line DAN-G was obtained from Deutsche Krebsforschungszentrum (Heidelberg, Germany). Dulbecco's modified Eagle medium (DMEM) and polyclonal antisera against PKC isoenzymes were obtained from Gibco (Berlin, Germany), and fetal calf serum from Biochrom (Berlin, Germany). Moloney murine leukaemia virus reverse transcriptase (M-MLV) was from Bethesda Research Laboratories (BRL, Bethesda, MD, USA); restriction enzymes from Boehringer Mannheim (Mannheim, Germany); Thermus aquaticus DNA polymerase from Promega (Heidelberg, Germany). All other chemicals were of analytical grade and purchased from Sigma (Deisenhofen, Germany).

\section{Cell culture}

All cell lines were grown as subconfluent monolayer cultures supplemented with $10 \%$ ( $\mathrm{vol} / \mathrm{vol})$ fetal calf serum, penicillin (100 $\mathrm{U} / \mathrm{ml})$, and streptomycin $(100 \mathrm{U} / \mathrm{ml})$. The cells were kept under $95 \%$ air and $5 \% \mathrm{CO}_{2}$ at $37^{\circ} \mathrm{C}$. All experiments were performed in the log phase of growth after the cells had been plated for 24 hours unless otherwise stated. Human recombinant IFN $\alpha$ was kindly provided by Hoffmann-LaRoche (Basel, Switzerland). Control cells received the same amount of vehicle. Cell viability was routinely checked by trypan blue exclusion and was consistently found to be $>95 \%$.

\section{Growth assays}

After mild trypsinisation, cells were plated in $22 \mathrm{~mm}$ culture dishes at a density of 100000 cells/well in the presence of DMEM containing $10 \%$ fetal calf serum. After an attachment period of 24 hours IFN $\alpha$ was added from a stock solution in the appropriate concentration. Control cells received vehicle alone. At the indicated times, cells were washed with $154 \mathrm{mM} \mathrm{NaCl}$ and then harvested by trypsinisation. Cells were then resuspended in phosphate buffered saline to ensure a single cell suspension. Viable cells were counted in a haemocytometer by trypan blue exclusion. Triplicate wells were analysed for each time point.

\section{Human tumour clonogenic assay (HTCA)}

For evaluation of clonal growth of the pancreatic tumour cell lines a methylcellulose HTCA was used. Cells were detached by trypsinisation and washed with their own growth medium, resuspended with $1 \mathrm{ml}$ RPMI 1640 (GIBCO, Berlin, Germany) plus 10\% fetal calf serum and counted by trypan blue staining to yield a final concentration of $3 \times 10^{4}$ cells $/ \mathrm{ml}$. Viability of the cells $>95 \%$ was required before cells were taken for an experiment. Methylcellulose solution was produced by boiling $0.5 \mathrm{l}$ distilled water with $21 \mathrm{~g}$ of methylcellulose. Five hundred $\mathrm{ml}$ cold Iscoves modified Dulbecco's medium (double concentrated, GIBCO, Berlin, Germany) was added to the methylcellulose after cooling down to $37^{\circ} \mathrm{C}$. The mixture was kept in $3.6 \mathrm{ml}$ aliquots at $-20^{\circ} \mathrm{C}$. Agar was made by boiling $3 \mathrm{~g}$ Difco agar (Agar Noble; Difco Lab, Detroit, MI, USA) in $100 \mathrm{ml}$ distilled water for 30 minutes and consecutively $10 \mathrm{ml}$ of the boiled agar were added to $20 \mathrm{ml}$ RPMI 1640 prewarmed to $37^{\circ} \mathrm{C}$. The incubation mixture was made up of $3.6 \mathrm{ml}$ methylcellulose solution, $2.7 \mathrm{ml}$ Hyclone fetal calf serum, $0.06 \mathrm{ml}$ mercaptoethanol, $0.3 \mathrm{ml}$ cell suspension, $0.8 \mathrm{ml}$ Iscove's, and $1.6 \mathrm{ml}$ Agar/RPMI 1640 mixture. This incubation mixture was vortexed thoroughly and kept in the dark at $37^{\circ} \mathrm{C}$ for 20 minutes. IFN $\alpha$ or control vehicle were added to $35 \mathrm{~mm}$ dishes as a solution of $0.1 \mathrm{ml}$ RPMI 1640 containing $0 \cdot 1 \%$ bovine serum albumin. An aliquot of $1 \mathrm{ml}$ of the incubation mixture was then added to the $35 \mathrm{~mm}$ dishes. This final incubation mixture contained the final IFN $\alpha$ concentrations as indicated in the results, thus tumour cells were exposed to IFN $\alpha$ for the complete assay period. The colony formation was evaluated with an inverted microscope after an incubation period of 10 days at $37^{\circ} \mathrm{C}$, $\mathrm{pH} 7 \cdot 2$, and $5 \% \mathrm{CO}_{2}$. Only colonies containing more than 20 cells were counted.

\section{Western blotting}

Cells were washed twice with phosphate buffered saline (PBS) and detached from culture dishes with a plastic cell scraper. Cells were homogenised in PBS containing $1 \mathrm{mM}$ phenyl-methyl-sulphonyl-fluorid (PMSF), 1 $\mathrm{mM} \mathrm{MgCl}$ and $20 \mathrm{mg} / \mathrm{ml} \mathrm{DNase}$ by 25 up and down strokes in a tightly fitting glass homogeniser. After incubation at room temperature for 30 minutes, $2 \mathrm{mM}$ EDTA was added followed by a short low-speed centrifugation step. Protein concentration was determined according to Bradford ${ }^{10}$ using the BioRad reagent (BioRad, Richmond, USA). Fifty $\mu \mathrm{g}$ protein for each condition were separated by $7 \cdot 5 \%$ SDS-PAGE (sodium dodecylsulphate polyacrylamide gelelectrophoresis) and electroblotted onto nitrocellulose. Filters were blocked in PBS, 0.05\% TWEEN 20 and $1 \%$ bovine serum albumin (BSA) for one hour at room temperature. PKC isoenzymes were detected by monospecific polyclonal antibodies (GIBCO) following the instructions provided by the supplier. After sequentially washing the filters with PBS, 0.05\% TWEEN 20, $0.05 \%$ Triton-X 100/PBS, TWEEN 20, $0.5 \mathrm{M} \mathrm{NaCl} / \mathrm{PBS}, 0.05 \%$ TWEEN 20, detection was performed using a second alkaline phosphatase conjugated antirabbit antibody. The detected signal was quantified by laser densitometry.

\section{Reverse transcriptase - polymerase chain reaction} (RT-PCR) analysis

Reverse transcription of RNA from cell lines was performed using $1 \mu \mathrm{g}$ total RNA, $100 \mathrm{pM}$ random hexamer primer, $1 \mathrm{mM}$ dithiotreiol, 6 $\mathrm{mM} \mathrm{Mg}{ }^{2+}, 500 \mu \mathrm{M}$ of each dNTP, 20 units RNAsin (Promega, Heidelberg, Germany) and Moloney murine leukaemia virus reverse transcriptase. The reverse transcriptase mixture 


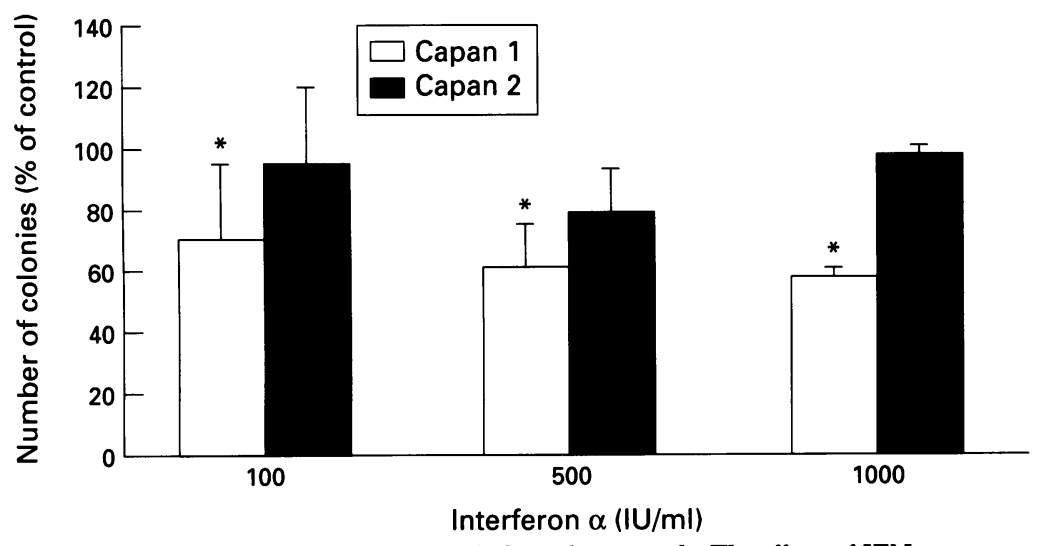

Figure 1: Effects of IFN $\alpha$ on anchorage independent growth. The effects of IFN $\alpha$ on anchorage independent growth of Capan 1 and Capan 2 cells were analysed in a human tumour clonogenic assay as described in 'Methods'. Cells were treated with the indicated concentrations of IFN $\alpha$ or vehicle and the number of colonies was determined after 10 days. Shown is the mean (SEM) of six independent experiments, each performed in triplicate $\left({ }^{\star} p<0 \cdot 05\right)$. was used directly as a template for PCR in a 1:20 dilution. For amplification, the following receptor specific 5'-primers and 3 'primers were designed complementary to the human IFN $\alpha$ receptor nucleotide sequence ${ }^{11}$ : 5'-AGCGATGAGTCTGTCGGG-3' and 5'GGCGTGGAGCCACTGAAC-3'. The expected molecular size of the PCR amplification product was $639 \mathrm{bp}$. The reaction was carried out in $10 \mathrm{mM}$ TRIS-HCl buffer (pH 9.0) containing $50 \mathrm{mM} \mathrm{KCl}, 0.01 \%$ Triton $\mathrm{X}-100,1$ $\mathrm{mM} \mathrm{MgCl} 2,200 \mu \mathrm{M}$ of each dNTP,50 pM of each primer and $2.5 \mathrm{U}$ Thermus aquaticus DNA polymerase in a final volume of $50 \mu \mathrm{l}$. Amplification conditions for 35 cycles were carried out as follows: denaturation for 30 seconds at $92^{\circ} \mathrm{C}$, annealing at $60^{\circ} \mathrm{C}$ for 90 seconds, extension for 90 seconds at $72^{\circ} \mathrm{C}$ with increasing five seconds each cycle. Extension was carried out for an additional 10 minutes after completion of all 35 cycles.

Electrophoretic mobility shift assay

Nuclear extracts from Capan 2 cells were prepared by the micropreparation technique,

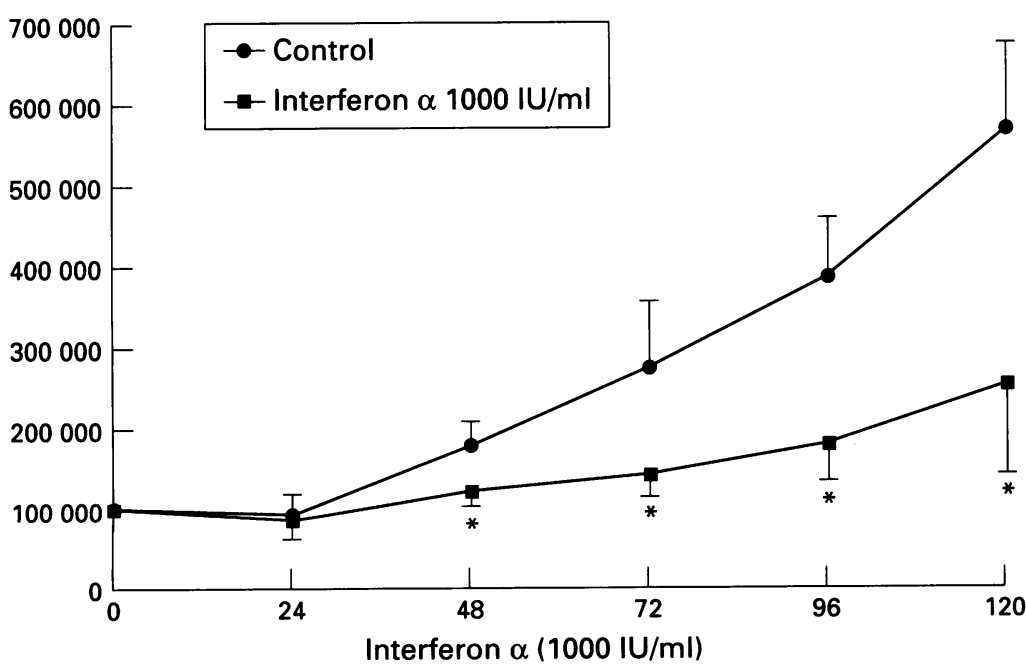

Time (h)

Figure 2: Effects of IFN $\alpha$ on anchorage dependent growth. Capan 1 cells (10 5 per plate) were incubated with vehicle or IFN $\alpha(1000 \mathrm{IU} / \mathrm{ml})$. At the indicated time points cells were were incubated with vehicle or IFN $\alpha$ (1000 IU/ml). At the indicated time points cells $\left({ }^{\star} p<0.05\right)$. exactly as previously described. ${ }^{11}$ Three $\mu$ g of nuclear protein extracts were incubated on ice for 15 minutes with $2 \mu \mathrm{g}$ of poly [d(I-C)]/poly [(I-C)] in $20 \mathrm{mM}$ TRIS- $\mathrm{HCl} \mathrm{pH} 7 \cdot 9,1 \mathrm{mM}$ EDTA, $0 \cdot 1 \%$ NP-40, $1 \mathrm{mM}$ dithiotreitol, $6.25 \%$ Ficoll, $0 \cdot 1 \mu \mathrm{g} / \mu \mathrm{l}$ BSA in a final reaction volume of $25 \mu$ l. Electrophoretic mobility shift assays were performed with a double stranded oligonucleotide corresponding to the sequence -113 to -74 of the human $2-5(\mathrm{~A})$-synthetase gene encoding the ISRE region: 5'CTCCTCCCTTCTGAGGAAACGAAACC AACAGCAGTCCAAG-3'.12 The oligonucleotide was end labelled with $\left[\gamma-{ }^{32} \mathrm{P}\right]-\mathrm{ATP}$ by a $\mathrm{T} 4$ polynucleotide kinase reaction and unincorporated nucleotides were removed by passing the reaction mixture over a DE52 anion exchange column (Whatman, Maidstone, England). A total of $0.5 \mathrm{ng}$ radioactively labelled double stranded oligonucleotide was added to each reaction and incubated for 30 minutes at room temperature. For quantitative comparisons competition experiments were performed by adding a 50 -fold to 100 -fold molar excess of unlabelled oligonucleotide to the reaction before adding the radioactive probe. The samples were then loaded on a $6 \%$ polyacrylamide gel containing $0.5 \times \mathrm{TBE}$ and $10 \%$ glycerine $(\mathrm{w} / \mathrm{v})$. The gel was run at $250 \mathrm{~V}$ in $0.5 \times \mathrm{TBE}$ at $4^{\circ} \mathrm{C}$ or three to four hours and subsequently fixed, dried, and exposed to $x$ ray film. Scanning of the autoradiogram was performed by a laser scanner (Biometra, Germany).

\section{Statistics}

Results were evaluated statistically by the Mann-Whitney test. p Values $<0.05$ were considered to be significant.

\section{Results}

Differential regulation of growth by IFN $\alpha$

We initially evaluated the effects of IFN $\alpha$ on two human ductal pancreatic carcinoma cell lines, Capan 1 and Capan 2. We have previously shown by intermediate filament phenotyping, that both cell lines express the cytokeratins $7,8,18$, and 19 , which is identical to the expression pattern seen in untransformed human pancreatic ductal cells. ${ }^{13,14}$ In a human tumour clonogenic assay, IFN $\alpha$ treatment resulted in a dose dependent decrease of anchorage independent growth in Capan 1 cells (Fig 1). Significant inhibition of growth was seen starting at a minimal concentration of $100 \mathrm{IU} / \mathrm{ml}$ and was maximal at $1000 \mathrm{IU} / \mathrm{ml}$ of IFN $\alpha$ mean (SEM) (58 (4)\% of control, $n=6$, $\mathrm{p}<0.05)$. In contrast, no significant growth inhibition by IFN $\alpha$ could be seen in the Capan 2 cell line at concentrations of up to 1000 $\mathrm{IU} / \mathrm{ml}$ of IFN $\alpha$ (Fig 1). We next analysed the effects of IFN $\alpha$ on anchorage dependent growth in both cell lines. Incubation of Capan 1 cells with IFNa at a concentration of 1000 $\mathrm{IU} / \mathrm{ml}$ resulted in a time dependent inhibition of anchorage dependent growth (Fig 2). The growth inhibitory effects of IFN $\alpha$ were 


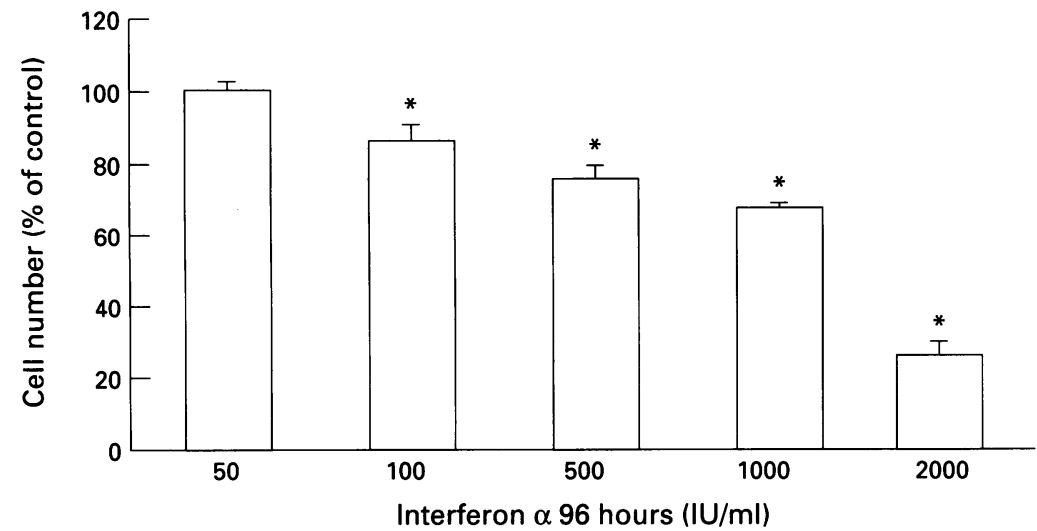

Figure 3: Antiproliferative effects of IFN $\alpha$ are dose dependent. Capan 1 cells were incubated with the indicated concentrations of IFN $\alpha$ for 96 hours. Cell number was then determined in triplicate. Cell viability was routinely judged by trypan blue exclusion and consistently found $>95 \%$ at IFN $\alpha$ concentrations up to $1000 \mathrm{IU} / \mathrm{ml}$. Shown is the mean (SEM) of four independent experiments, each performed in triplicate $\left.{ }^{\star} p<0.05\right)$.

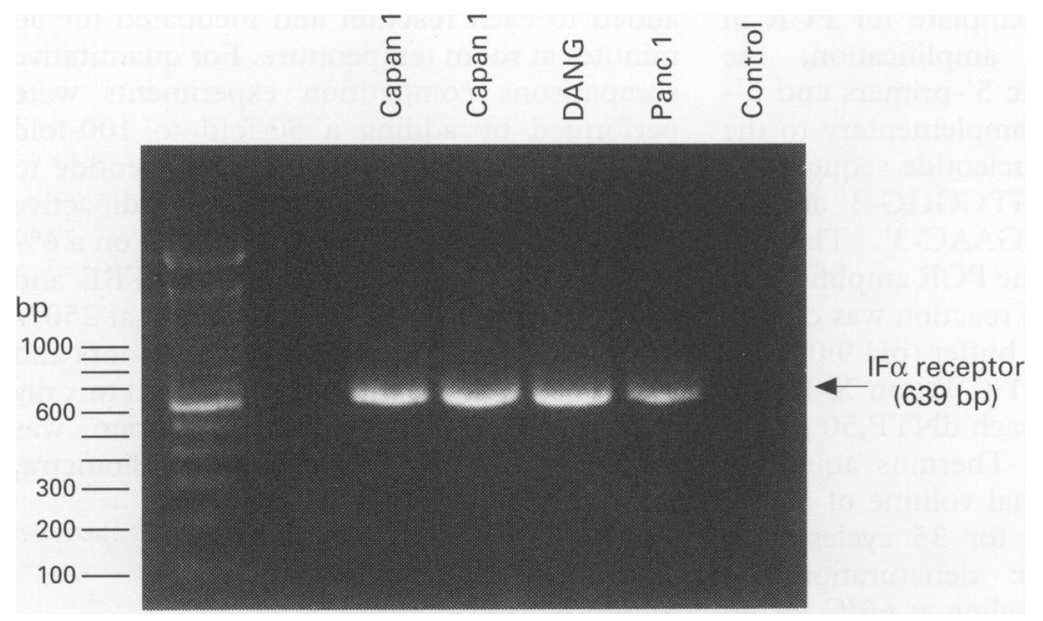

Figure 4: Pancreatic carcinoma cells express IFN $\alpha$ receptors. RT-PCR analysis was performed using specific primers for the human IFN $\alpha$ receptor. The expected size of the amplification product ( $639 \mathrm{bp}$ ) was confirmed by a DNA molecular weight ladder. Shown is a representative of three independent experiments.

significant as early as 48 hours $(72(4 \cdot 5) \%$ of control, $\mathrm{n}=5, \mathrm{p}<0.05)$ and reached a maximum after 120 hours $(27(6.9) \%$ of control, $n=5$, $\mathrm{p}<0.05)$. In analogy of the clonogenic assay, we did not see a growth inhibition of Capan 2 cells under identical experimental conditions (data not shown). The antiproliferative effects of IFN $\alpha$ on Capan 1 cells were dose dependent (Fig 3). Increasing the IFN $\alpha$ concentration to $2000 \mathrm{IU} / \mathrm{ml}$ resulted in a pronounced decrease of cell number (Fig 3). However, when judging cell viability by routinely performed trypan blue exclusion, a considerable number of cells stained positive, indicating a cytotoxic rather than a cytostatic effect of IFN $\alpha$ at a concentration of $2000 \mathrm{IU} / \mathrm{ml}$. In contrast, trypan blue exclusion revealed more than $95 \%$ viable cells at IFN $\alpha$ concentrations up to 1000 $\mathrm{IU} / \mathrm{ml}$.

Human pancreatic carcinoma cell lines express functional IFN $\alpha$ receptors

We then investigated, whether the observed differences in IFN $\alpha$ sensitivity might be explained by differential expression of the IFN $\alpha$ receptor. Using the highly sensitive RTPCR approach, we designed primers specific
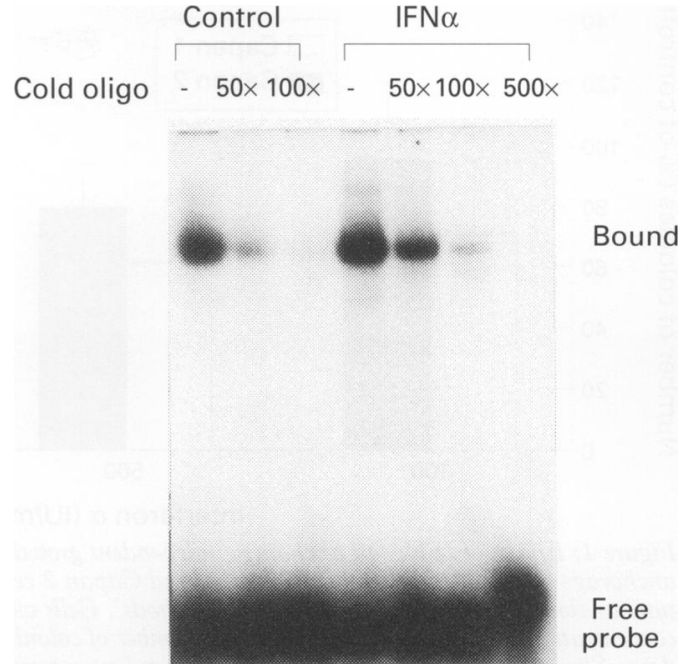

Figure 5: Effects of IFN $\alpha$ on DNA binding to an ISRE consensus sequence in Capan 2 cells. Capan 2 cells were either treated with vehicle (control) of IFN $\alpha(1000 \mathrm{IU} / \mathrm{ml})$ for one hour. Nuclear extracts were then prepared and electrophoretic mobility shift assays performed as outlined in 'Methods'. ISRE consensus sequence specific competition was performed by 50-fold and 100-fold molar excess of unlabelled oligonucleotide. Shown is a representative of two experiments yielding identical results.

for the human IFN $\alpha$ receptor nucleotide sequence. ${ }^{15}$ As Figure 4 shows, all four human pancreatic carcinoma cell lines express IFN $\alpha$ receptor transcripts, as evidenced by the detection of the expected $639 \mathrm{bp}$ amplification product. To ensure that the detected signal was not due to amplification of genomic DNA, an internal control without prior reverse transcription was included, which was repeatedly negative (Fig 4). No difference regarding the RT-PCR amplification products was seen between Capan 1 and Capan 2 cells, indicating that a loss of IFN $\alpha$ receptor expression is not primarily responsible for the IFN $\alpha$ resistance seen in Capan 2 cells. To further confirm that the IFN $\alpha$ receptor is functionally active in Capan 2 cells, we performed electrophoretic mobility shift assays using an ISRE consensus oligonucleotide. As Figure 5 shows, incubation of Capan 2 cells with IFN $\alpha$ for one hour resulted in a threefold increase of DNA binding to the ISRE consensus sequence, indicating the presence of functionally active IFN $\alpha$ receptors in Capan 2 cells.

\section{Differential regulation of PKC isoenzymes by} IFN $\alpha$

Because PKC isoenzymes have recently been implicated to play a key part in mediating the antiproliferative effects of IFN $\alpha,{ }^{6-9}$ we hypothesised that differential PKC isoenzyme expression or regulation by IFN $\alpha$ might explain the observed differences in the antiproliferative action on Capan 1 and Capan 2 cells. Pilot experiments using monospecific antibodies and competing synthetic peptides showed that both cell lines express PKC isoenzymes $\alpha$ and $\zeta$. In contrast, no expression of PKC isoenzymes $\beta, \gamma, \delta$, and $\epsilon$ could be observed, although all of these isoenzymes could be clearly detected in rat brain, which 

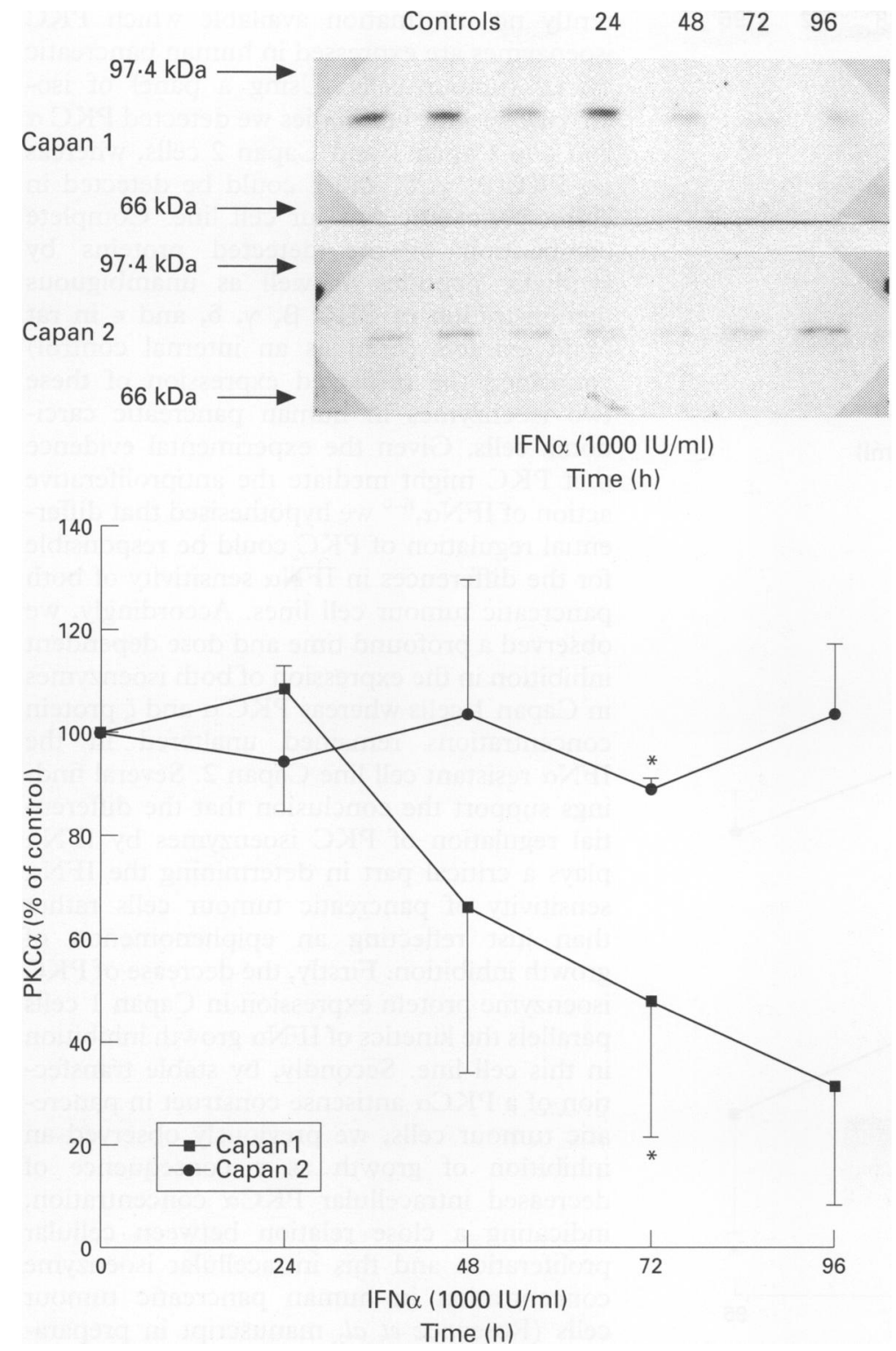

Figure 6: Differential regulation of $P K C \alpha$ by IFN $\alpha$. Capan 1 and Capan 2 cells were incubated with vehicle or IFN $\alpha(1000 \mathrm{IU} / \mathrm{ml})$ for the indicated time points. PKC $\alpha$ concentrations were then determined by western blotting using a monospecific antibody. Shown is a representative western blot as well as the summary of three independent experiments. PKC $\alpha$ concentrations were expressed as \% of three untreated controls. Shown is the mean $(S E M)\left({ }^{*} p<0.05\right)$. was used as an internal control (data not shown). We next investigated the effects of IFN $\alpha$ on PKC isoenzyme expression in both cell lines by western blotting. In Capan 1 cells, IFN $\alpha$ treatment $(1000 \mathrm{IU} / \mathrm{ml})$ resulted in a pronounced time dependent decrease of PKC $\alpha$ concentration (Fig 6). This decrease was seen as early as 48 hours and reached a maximum after 96 hours of IFN $\alpha$ treatment (31 (22) $\%$ of control, $n=3, p<0.05$ ). In contrast, PKC $\alpha$ concentrations were not changed by IFN $\alpha$ in Capan 2 cells (103 (13)\% of control, $n=3$ ) (Fig 6). In analogy to these experiments, we observed a very similar expression pattern for PKC $\zeta$ after IFN $\alpha$ treatment (Fig 7). In Capan 1 cells, PKC $\zeta$ protein concentrations were decreased by IFN $\alpha$ in a time dependent manner with a maximum observed after 96 hours of treatment (34 (21), $n=3, p<0.05)$. In Capan 2 cells however, no significant change of PKC $\zeta$ expression was seen during the complete time course of IFN $\alpha$ treatment (Fig 7).

\section{Discussion}

The results of conventional chemotherapy in the treatment of advanced human pancreatic adenocarcinoma have been disappointing. Recently, in vivo and in vitro experimental evidence has accumulated, suggesting that the combination of classic cytotoxic drugs (for example, 5-FU) with IFN $\alpha$ might be superior to conventional chemotherapy alone. ${ }^{16-18}$ Subsequent clinical trials have shown some limited responses in pancreatic cancer patients using the combination of $5-\mathrm{FU}$ and $\mathrm{IFN} \alpha{ }^{19}$ indicating that some tumours are IFN $\alpha$ sensitive while others are resistant to the antiproliferative effects of IFN $\alpha$. To establish a rational approach for IFN $\alpha$ treatment of pancreatic carcinoma patients it is therefore essential to understand and characterise parameters at a cellular level that will determine whether a given tumour cell will or will not respond to the antiproliferative action of IFN $\alpha$. To consider this problem, we have established an in vitro system of two human pancreatic ductal tumour cell lines, potentially reflecting the clinical situation of an IFN $\alpha$ sensitive (Capan 1 cells) and an IFN $\alpha$ resistant (Capan 2 cells) pancreatic tumour. Treatment with IFN $\alpha$ results in a time and dose dependent inhibition of anchorage dependent and anchorage independent growth in Capan 1 cells. In pharmacological relevant concentrations (up to $1000 \mathrm{IU} / \mathrm{ml}$ ), the antiproliferative effects of IFN $\alpha$ were due to growth inhibition rather than cytotoxic effects, which is evidenced by unaltered cell viability after IFN $\alpha$ treatment compared with control cells. In contrast, no antiproliferative effects of IFN $\alpha$ could be observed under identical experimental conditions in the Capan 2 cell line, suggesting that these cells are resistant to the growth inhibitory effects of IFN $\alpha$. This in vitro system therefore provides a suitable model to study the cellular mechanisms responsible for the differential IFN $\alpha$ sensitivity. The first step in IFN $\alpha$ action is binding to a high affinity membrane receptor. Therefore, loss of receptor expression or function (which frequently occurs during malignant transformation) could be responsible for the IFN $\alpha$ resistance observed in Capan 2 cells. However, using the highly sensitive RT-PCR technique and electrophoretic mobility shift assays, we were able to show functionally active IFN $\alpha$ receptors in both cell lines, indicating that a loss of receptor expression or function is not primarily responsible for IFN $\alpha$ resistance in Capan 2 cells. The molecular mechanisms by which IFN $\alpha$ exerts its antiproliferative effects after receptor binding are poorly understood. After binding to its receptor, IFN $\alpha$ rapidly induces transcription of a variety of cellular genes summarised as IFN stimulated genes (IFSG); the biological function of these IFSG is not completely understood and their involvement in mediating the antiproliferative action of IFN $\alpha$ is currently unclear. ${ }^{5}$ The rapid and transient kinetics of their transcriptional induction suggests that the IFSG might not exclusively mediate the growth regulatory effects of interferons.

Recent experimental evidence suggests that 

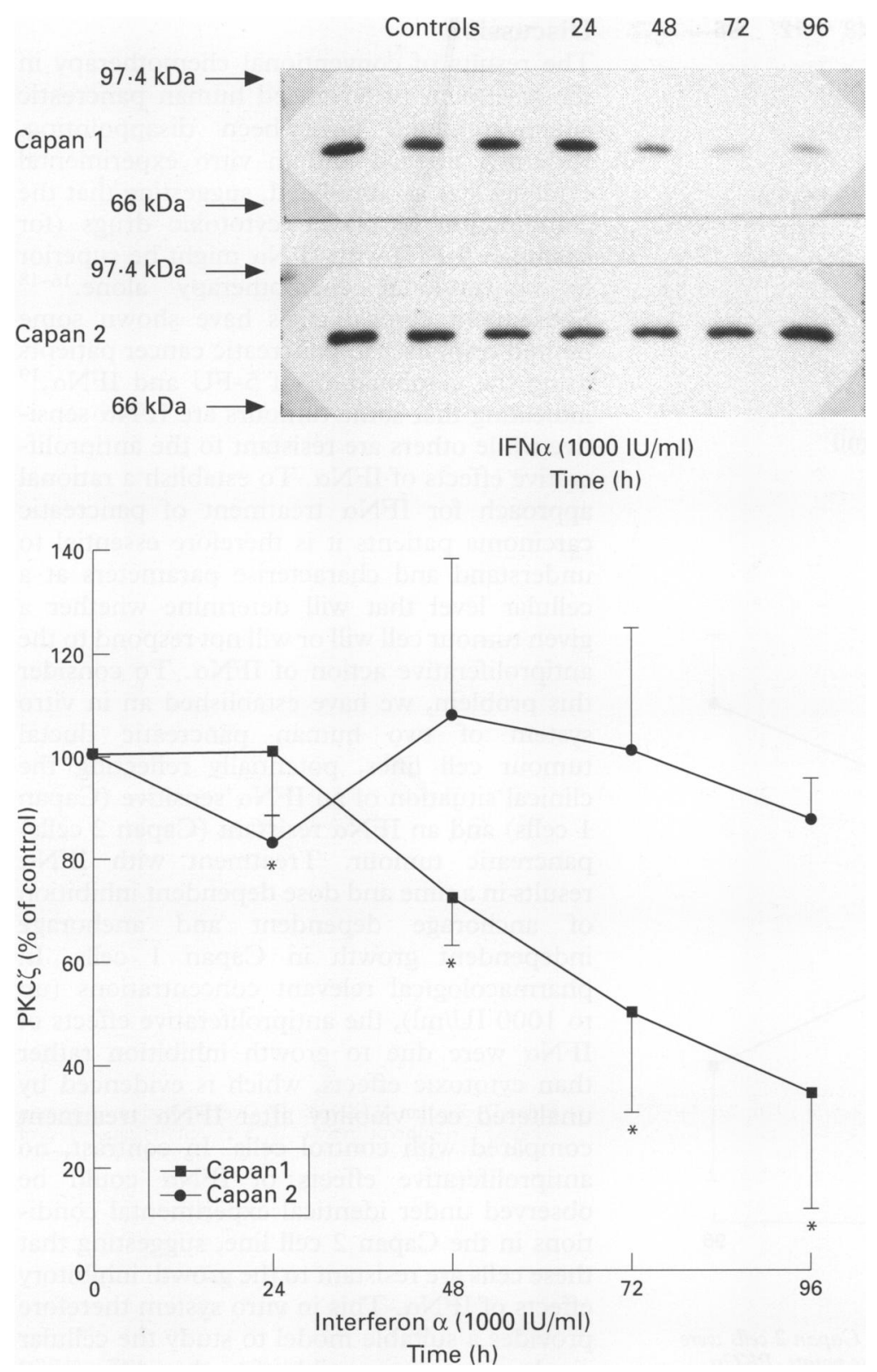

Figure 7: Differential regulation of PKC $\zeta$ by IFN $\alpha$. Capan 1 and Capan 2 cells were incubated with vehicle or IFN $\alpha$ (1000 IU/ml) for the indicated time points. PKC $\zeta$ concentrations were then determined by western blotting using a monospecific antibody. Shown is a representative western blot as well as the summary of three independent experiments. PKC $\zeta$ concentrations were expressed as \% of three untreated controls. Shown is the mean $(S E M)\left({ }^{*} p<0.05\right)$. rently no information available which PKC isoenzymes are expressed in human pancreatic ductal tumour cells. Using a panel of isoenzyme specific antibodies we detected PKC $\alpha$ and $\zeta$ in Capan 1 and Capan 2 cells, whereas no PKC- $\beta, \gamma, \delta$, and $\epsilon$ could be detected in either pancreatic tumour cell line. Complete competition of the detected proteins by synthetic peptides as well as unambiguous demonstration of PKC $\beta, \gamma, \delta$, and $\epsilon$ in rat brain extracts (used as an internal control) confirmed the restricted expression of these two isoenzymes in human pancreatic carcinoma cells. Given the experimental evidence that PKC might mediate the antiproliferative action of IFN $\alpha,{ }^{6-9}$ we hypothesised that differential regulation of PKC could be responsible for the differences in IFN $\alpha$ sensitivity of both pancreatic tumour cell lines. Accordingly, we observed a profound time and dose dependent inhibition in the expression of both isoenzymes in Capan 1 cells whereas PKC $\alpha$ and $\zeta$ protein concentrations remained unaltered in the IFN $\alpha$ resistant cell line Capan 2. Several findings support the conclusion that the differential regulation of PKC isoenzymes by IFN $\alpha$ plays a critical part in determining the IFN $\alpha$ sensitivity of pancreatic tumour cells rather than just reflecting an epiphenomenon of growth inhibition. Firstly, the decrease of PKC isoenzyme protein expression in Capan 1 cells parallels the kinetics of IFN $\alpha$ growth inhibition in this cell line. Secondly, by stable transfection of a PKC $\alpha$ antisense construct in pancreatic tumour cells, we previously observed an inhibition of growth as a consequence of decreased intracellular PKC $\alpha$ concentration, indicating a close relation between cellular proliferation and this intracellular isoenzyme concentration in human pancreatic tumour cells (Rosewicz et al, manuscript in preparation). Thirdly, a direct relation between the intracellular PKC $\alpha$ concentration and the rate of proliferation has been described in vivo and in vitro for such divergent tissues as astrocytomas, fibroblasts, and myeloid progenitor cells, ${ }^{28-30}$ suggesting the central role of PKC $\alpha$ as a key target by which cytokines and hormones regulate cellular growth. Finally, treatment of human pancreatic carcinoma cell lines with phorbolesters, which results in down regulation and therefore depletion of intracellular PKC $\alpha$ protein concentrations, leads to profound inhibition of cellular proliferation. ${ }^{31,32}$ Because information on the gene and promotor structure of PKC isoenzymes is (to date) very limited, little is currently known on how the expression of PKC isoenzymes is regulated. ${ }^{33}$ The lag period of 24 to 48 hours observed for the inhibition of PKC expression by IFN $\alpha$ makes a direct transcriptional modulation unlikely. Whether transacting transcriptional effects or posttranscriptional mechanisms are operative remains unclear and is currently under investigation. The inability of IFN $\alpha$ to inhibit PKC expression in Capan 2 cells might be due to the cell type specific expression of proteins required for the inhibition of PKC expression by IFN $\alpha$. PKC isoenzymes are expressed in a tissue specific and developmentally regulated fashion, suggesting that different isoenzymes serve distinct biological functions through differences in activator or substrate specificity, or both. ${ }^{25-27}$ To our knowledge, there is cur- 
In summary, we have shown for the first time that human ductal pancreatic carcinoma cells express exclusively PKC isoenzymes $\alpha$ and $\zeta$. The ability to inhibit the expression of PKC $\alpha$ and $\zeta$ might predict the antiproliferative action of IFN $\alpha$ and thus provides one step ahead for a rational and selected therapeutic approach to pancreatic carcinoma patients. This work was supported by a grant from the Deutsche
Forschungsgemeinschaft (Ro 674/3-3) and the Deutsche Krebshilfe.

1 Silverberg E, Boring CC, Squires TS. Cancer statistics 1990. Can Canc f Clinicians 1990; 40: 9-26.

2 Bakkevold KE, Arnesjo B, Kambestag B. Carcinoma of the pancreas and papilla of Vater: presenting symptoms, signs, and diagnosis related to stage and tumor site. A prospective multicentre trial in 472 patients. Scand $\mathcal{f}$ prospective multicentre trial in

3 Arbuck SG. Chemotherapy for pancreatic cancer. Baillières Clin Gastroenterol 1990; 4: 953-64.

4 Wadler S, Schwartz EL. Antineoplastic activity of the combination of interferon and cytotoxic agents against experimental and human malignancies: a review. Cancer Res 1990; 50: 3473-86.

5 Sen GC, Lengyel P. The interferon system. $f$ Biol Chem 1992; 267: 5017-20.

6 Pfeffer LM, Eisenkraft BL, Reich NC, Improta T, Baxter G, Daniel-Issakani $\mathrm{S}$, et al. Transmembrane signalling by Daniel-Issakani $S$, et al. Transmembrane signalling by interferon $\alpha$ involves diacylglycerol production and activation of the $\epsilon$ isoform of protein kinase $C$ in

7 Pfeffer LM, Strulovici B, Saltiel AR. Interferon- $\alpha$ selectively activates the $\beta$-isoform of protein kinase $C$ through phosphatidylcholine hydrolysis. Proc Natl Acad Sci USA 1990, 87: 6537-41.

8 Kessler DS, Levy DE. Protein kinase activity required for an early step in interferon- $\alpha$ signaling. 7 Biol Chem $1991 ; 266$ : 23471-6

9 Csermely P, Balint E, Grimley PM, Aszalos A. Protein kinase $C$ is involved in the early signals of interferon- $\alpha$ but
not of interferon- $\gamma$ in U937 cells. $\mathcal{F}$ Interferon Res 1990; 10: not of inter 11 .

10 Bradford $M$. A rapid and sensitive method for the quantitation of microgram quantities of protein using the principle of protein-dye binding. Anal Biochem 1976; 72: 248-54.

11 Nancy CA, Faller DV. A rapid micropreparation technique for extraction of DNA-binding proteins from limitin numbers of mammalian cells. Nucleic Acids Res 1991; 19: 2499-554.

12 Kumar R, Korutla L, Zhang K. Cell-cycle dependent modulation of alpha-interferon inducible gene expression and activation of signaling components in Daudi cells. $\mathcal{f} \mathrm{Biol}$ Chem 1994; 269: 25437-41.

13 Rosewicz S, Stier U, Brembeck F, Kaiser A, Papadimitriou CA, Berdel WE, et al. Retinoids: effects on growth, differentiation and nuclear receptor expression in human pancreatic carcinoma cell lines. Gastroenterology 1995; 109: 1646-60

14 Schüssler MH, Skoudy A, Ramaekers F, Real FX. Intermediate filaments as differentiation markers of normal pancreas and pancreas cancer. Am F Pathol 1992; 140: 559-68.

15 Uze G, Lutfalla G, Gresser I. Genetic transfer of a func- tional human interferon- $\alpha$ receptor into mouse cells: cloning and expression of its cDNA. Cell 1990; 60 225-34.

16 Wilke HJ, Schmoll HJ, Preusser P, Fink U, Meyer HJ, Achterrath $\mathrm{W}$, et al. Biochemical modulation of 5 -fluorouracil by folinic acid or alpha-interferon with and without other cytostatic drugs in gastric, esophageal and pancreatic cancer Semin Oncol 1992. 19: 215-9.

17 Rustum YM. Rational basis for the metabolic modulation of 5 -fluorouracil by leucovorin and interferon-alpha. $B r \mathcal{F}$ 5-fluorouracil by leucovo

18 Gresser I. Antitumor effects of interferons: past, present and future. Br 7 Haematol 1991; 79: 1-5.

19 Derderian P, Pazdur R, Ajani J. Phase II study of 5-fluorouracil and recombinant alpha-2a interferon in the treatment of advanced pancreatic carcinoma. Proc Am Soc Clin Oncol 1991; 147: 10

20 Constaninescu SN, Cernescu C, Balta F, Maniu H, Popescu LM. The priming effect of human interferonalpha is mediated by Protein kinase C. $\mathcal{F}$ Interferon Res 1990; 10: 589-97.

21 Nishizuka Y. The molecular heterogeneity of protein kinase $\mathrm{C}$ and its implications for cellular regulation. Nature 1988 334: 661-5.

22 Nishizuka Y. Intracellular signalling by hydrolysis of phospholipids and activation of protein kinase C. Science 1992; 258: $607-14$.

23 Kikkawa U, Kishimoto A, Nishizuka Y. The protein kinase C family: heterogeneity and its implications. Annu Rev Biochem 1989; 58: 31-44.

24 Stabel S, Parker PJ. Protein kinase C. Pharmacol Ther 1991; 51: 71-95.

25 Jelkman W, Huwiler A, Fandrey J, Pfeilschifter J. Inhibition of erythropoetin production by phorbol ester is associated with down-regulation of protein kinase C-alpha isoenwith down-regulation of protein kinase C-alpha isoenzyme in hepatoma

26 Persons DA, Owen RD, Ostrowski MC, Finn OJ. Protein kinase $\mathrm{C}$ gamma expression mimics phorbol ester induced transcriptional activation of a murine VL30 enhancer element. Cell Growth Differ 1991; 2: 7-14.

27 Akita Y, Ohno S, Yajima Y, Suzuki K. Possible role of calcium-independent protein kinase $\mathrm{C}$ isoenzyme, $\mathrm{PKC} \epsilon$, in chyrotropin-releasing hormone-sional transduction: trotropin-releasing horm Biochem Biophys Res Commun 1990; 172: 184-9.

28 Benzil DL, Finkelstein SD, Epstein MH, Finch PW. Expression pattern of $\alpha$-protein kinase $C$ in human astroExpression pattern of $\alpha$-protein kinase $C$ in human astrocytomas indicates

29 Eldar H, Zisman Y, Livneh E. Overexpression of protein kinase $C \alpha$-subtype in Swiss 3T3 fibroblasts causes loss of both high and low affinity receptor numbers for epidermal growth factor. F Biol Chem 1990; 265: 13290-6.

30 Katayama N, Nishiwaka M, Minami N, Shirakawa S. Putative involvement of protein kinase $\mathrm{C}$ in proliferation of human myeloid progenitor cells. Blood 1989; 73: 123-30.

31 Ohmura E, Wakai K, Isozaki O, Murakami H, Onoda M Emoto N, et al. Inhibition of human pancreatic cancer cell (Mia PaCa-2) growth by cholera toxin and 8-chloro(Mia PaCa-2) growth by cholera toxin and 8 in vitro. Br $\mathcal{C}$ Cancer 1993; 67: 279-83.

32 Ohmura E, Okada M, Onoda N, Kamiya Y, Murakami H, Tsushima $\mathrm{T}$, et al. Insulin-like growth factor I and transforming growth factor $\alpha$ as autocrine growth factors in human pancreatic cancer cell growth. Cancer Res 1990; 50: 103-7.

33 Hug H, Sarre TF. Protein kinase C isoenzymes: divergence in signal transduction? Biochem f 1993; 291: 329-43. 